\section{EMBRYAIDDLE Aeronautical University}

SCHOLARLY COMMONS
International Journal of Aviation, Aeronautics, and Aerospace

\title{
Experimental Evaluation of Strength Degradation Temperature for Carbon Epoxy Filament Wound Composite
}

Jai Krishna Mishra

Advanced Systems Laboratory, Hyderabad, India, jkmishra06@gmail.com Surya Prakash Rao CH Dr

National Institute of Technology, Warangal, India, cspr@nitw.ac.in Subhash Chandra Bose P Dr

National Institute of Technology, Warangal, India, subhash@nitw.ac.in

Kishore Nath N Dr

Advanced Systems Laboratory, Hyderabad, India, Ica_droptank@yahoo.com

Rama Rao Golla Mr

Advanced Systems Laboratory, Hyderabad, India, ramaraogolla@rediffmail.com

Follow this and additional works at: https://commons.erau.edu/ijaaa

Part of the Other Mechanical Engineering Commons, Space Vehicles Commons, and the Structures and Materials Commons

\section{Scholarly Commons Citation}

Mishra, J., CH, S. R., P, S. B., N, K., \& Golla, R. (2020). Experimental Evaluation of Strength Degradation Temperature for Carbon Epoxy Filament Wound Composite. International Journal of Aviation, Aeronautics, and Aerospace, 7(4). https://doi.org/10.15394/ijaaa.2020.1534

This Concept Paper is brought to you for free and open access by the Journals at Scholarly Commons. It has been accepted for inclusion in International Journal of Aviation, Aeronautics, and Aerospace by an authorized administrator of Scholarly Commons. For more information, please contact commons@erau.edu. 


\section{Experimental Evaluation of Strength Degradation Temperature for Carbon Epoxy Filament Wound Composite}

\section{Cover Page Footnote}

Deep gratitude is expressed for permission and support to carry out present studies for Dr MRM Babu, Distinguished Scientist, Director ASL and Dr. Manoj Kumar Burghoain, Scientist 'G', Tech Director, CPDC, ASL. Authors are also thankful to DTL, CPDC for providing testing support. 
Polymeric composites have been widely used in various structural and thermal aerospace applications (Rajak et al., 2019). Polymeric composites having high strength and high modulus reinforcement are ideally suited for lot of critical aerospace applications as structure is designed with high specific strength and high specific modulus (Muralidhara et al., 2020). In case of launch vehicles/ missiles, one such application is design and manufacturing of solid rocket motor casing with polymeric composites as it gives high performance and reduces inert weight of propulsion system. The high specific strength and high specific modulus of composite materials makes it ideal choice for designing the composite rocket motor case (CRMC). Mostly the CRMCs are designed with high strength and high modulus carbon fiber as reinforcement and Epoxy Resin as matrix (Sharma et al., 2020). These are manufactured with filament winding process. As per ASTM D 2290 test method, the apparent tensile strength can be evaluated by preparing ring specimens from filament wound shell which simulates the hoop winding and cylindrical geometry of composite motor case. Composite rocket motor casings are designed with optimum margin of safety to meet requirement of high internal pressure due to combustion of solid propellant. Solid rocket motors are designed with insulation system for internal surface to limit back wall temperature of casing with in design specification depending on casing material (Trudeau, 1990). However, during flight in trajectory, the temperature on external surface of rocket motor will rise due to kinetic heating as result of aerodynamic drag. In case of rocket motor casings made up of polymeric composites, this temperature rise on external surface is more critical than metallic casings. The mechanical properties of FRP composites degrades beyond certain temperature, depending primarily upon resin system and its glass transition temperature $(\mathrm{Tg})$. In present work, the method of ring fabrication using filament winding is used to prepare test samples to experimentally test and evaluate apparent tensile strength with temperature of Carbon Epoxy composite. The tensile test at ambient is also done on specimens made from carbon Epoxy laminate using filament winding technique and are compared with ring test results to establish correlation. The Glass Transition temperature (Tg) for Carbon Epoxy is also determined with Dry Scanning Calorimetry (DSC) technique.

\section{Filament Wound Composite Rocket Motor Case}

The filament winding process is one of the most widely used for composite pressure vessel manufacturing (Ford, 2020). This process is highly automated and precise as its execution involves multi axes CNC filament winding machine, winding program as per ply sequence and mandrels. The filament winding technique offers high production rate and ideally suits for tailoring of fibers in FRP structure as per design requirements. In filament winding technique, fibers are laid over mandrel based on winding program which in turns depends on stresses and 
design requirements in structure. This allows for optimal volume fraction of fibers in specific directions.

Rocket motor case is one of most important element of propulsion system. Rocket motor case is designed for high internal pressure and other structural load requirements of axial load and bending moment depending on overall mission objectives. Propellant is loaded in side case and ignited to produce high pressure which is expanded through nozzle to produce required thrust. The rocket motor cases are designed with metals and composite materials. Design of motor case with polymeric composite materials is boon as light weight structure with high strength is achieved which makes it ideal choice for rockets/aerospace applications. Polymeric composites consists of reinforcement and matrix (Raju \& Shanmugaraja, 2020). Reinforcements are principal load carrying elements and matrix acts as load transfer medium and keeps reinforcement at required locations and orientations (Shen al., 2020). Carbon \& Aramid/Kevlar fibers having high strength and high modulus ideally suited reinforcement along with Epoxy resin as matrix materials for design of composite rocket motor case (Muralidhara, 2020). Composite case primary design load is internal pressure and depending on design requirements stress are critical in domes or cylinder. The dome shapes of composite casing are very important from wet winding and stress distribution point of view. Rocket motor casing is basically a pressure vessel with specially designed metallic end fittings namely polar bosses and skirts. The end fittings are configured to suit the overall vehicle requirements for assembly/integration with adjoining airframe sections. The performance factor for composite case is high which contributes for overall high efficiency of propulsion system and drastic reduction in inert structural mass. If configuration constraints are not there, the rocket motor can be designed as a complete system and the casing can be designed to achieve the maximum efficiency with very high-performance factor. However usually there will be always configuration constraints from interface and other launch vehicle requirements which limits performance factor. In present case, CRMC is manufactured with High strength \& high modulus carbon fiber and Epoxy resin by wet filament winding process (Weber, 2017).

\section{Thermal Criticalities for Composite Rocket Motor Case}

Rocket motor case is loaded with composite propellant (Solid \& liquid ingredients, i.e. solid oxidiser, Liquid Binder Resin. Etc.) and when ignited produces high temperature gases at high pressure during action time of rocket motor. These gases are expanded through nozzle to produce required thrust. Rocket motors are designed with Insulation system between propellant and motor case internal surface to limit the internal surface temperature with in specified values considering motor action time.

Rocket motors are attached in launch vehicles/missiles through its end fittings and needs to meet additional functional requirements as vehicle structure. 
Vehicle accelerates continuously after lift-off as per trajectory design and mission objectives. During flight in trajectory, the temperature on external surface of rocket motor will rise due to kinetic heating as result of aerodynamic drag. In case of rocket motor casings made up of polymeric composites, this temperature rise on external surface is more critical than metallic casings. This aspect is mission critical and necessitates for testing \& evaluation of temperature at which composite material strength degradation begins. Experimental determination of glass transition temperature $(\mathrm{Tg})$ for Polymeric material which is used for rocket motor case is absolute essential. These inputs are very crucial for design considerations and various aspects regarding thermal protection system during powered phase of vehicle trajectory especially for rocket motor external surface.

\section{Material Description}

Polymeric composites which are used for design of filament wound rocket motor case have main constituents as continuous fibers as reinforcement and polymeric resins as matrix (Liu, Delong et al., 2018). The main fibres options meeting such requirements are Glass, Aramid/Kevlar \& PAN Carbon. PAN Carbon fiber is having high modulus \& high strength and used for present studies. Polymeric resins viz thermosetting and thermoplastic are options and Epoxy Resin which is thermosetting resin having good mechanical properties is used in present work (Liu, Shi et al., 2018). The details and specification of materials chosen for present studies are as follows:

\section{Carbon Roving}

Carbon roving as reinforcement having following specifications given in table 1 is considered for preparing samples in present work as same carbon roving is most widely used for design of composite rocket motor case. 
Table 1

Carbon Roving Properties

\begin{tabular}{|r|c|c|}
\hline \multicolumn{1}{|c|}{ S.No } & Property & Specification \\
\hline 1. & Tensile strength & $4.2 \mathrm{GPa}$ (Min.) \\
\hline 2. & Tensile Modulus & $220 \mathrm{GPa}$ (Min) \\
\hline 3. & Tow Size & 12 K (No twist/ never twisted \\
& & yarn) \\
\hline 4. & Tex & $600 \mathrm{~g} / \mathrm{Km}$ (nominal) \\
\hline 5. & Filament Diameter & $93 \%$ microns \\
\hline 6. & Carbon Content & 1.2 to $2 \%$ \\
\hline 7. & Sizing & Epoxy compatible $(0.8 \% \mathrm{Min})$ \\
\hline 8. & $\%$ Elongation & 1.7 to $1.85 \mathrm{~g} / \mathrm{cc}$ \\
\hline 9. & Density & \\
\hline
\end{tabular}

\section{Epoxy Resin}

Epoxy Resin with following specifications given in Table 2 is considered as matrix material: 
Table 2

Epoxy Resin \& Hardener Properties

\begin{tabular}{|c|c|c|}
\hline Sl. No & Property & Specification \\
\hline 1 & $\begin{array}{l}\text { Specific Gravity of Resin, at } \\
\qquad 25^{\circ} \mathrm{C}\end{array}$ & 1.15 to 1.20 \\
\hline 2 & Viscosity of Resin, at $25^{\circ} \mathrm{C}$ & $\begin{array}{l}15000 \text { to } 17000 \\
\text { cps }\end{array}$ \\
\hline 3 & $\begin{array}{l}\text { Volatile Content of Resin (\% } \\
\text { by wt.) }\end{array}$ & $<1.5 \%$ \\
\hline 4 & $\begin{array}{l}\text { Epoxy Content of Resin } \\
\text { (Eq/Kg of resin) }\end{array}$ & 5.0 to 5.45 \\
\hline 5 & $\begin{array}{l}\text { Specific Gravity of Hardener at } \\
\qquad 25^{\circ} \mathrm{C}\end{array}$ & 1.02 \\
\hline 6 & Viscosity of Hardener, at $25^{\circ} \mathrm{C}$ & $152 \mathrm{cps}$ \\
\hline 7 & $\begin{array}{c}\text { Initial mix viscosity of Resin \& } \\
\text { Hardener, at } 25^{\circ} \mathrm{C}\end{array}$ & $6350 \mathrm{cps}$ \\
\hline 8 & $\begin{array}{c}\text { Initial mix viscosity of Resin \& } \\
\text { Hardener, at } 45^{\circ} \mathrm{C}\end{array}$ & $950 \mathrm{cps}$ \\
\hline 9 & Gel time of Resin mix at $100^{\circ} \mathrm{C}$ & 140 \\
\hline 10 & Tensile strength & $60 \mathrm{MPa}$ \\
\hline 11 & Tensile Modulus & $2.4 \mathrm{GPa}$ \\
\hline 12 & $\%$ elongation & 4.2 \\
\hline
\end{tabular}




\section{Test Plan and Methodology}

In present studies, the test scheme being followed along with methodology is described as follows:

\section{Test-1}

Experimental characterization for mechanical properties viz Tensile strength, tensile modulus, Poisons ratio and Ultimate failure strain on specimens made from UD Carbon Epoxy Laminate as per ASTM D 3039 at ambient temperature.

\section{Test-2}

Experimental evaluation of apparent tensile strength on Carbon Epoxy filament wound ring specimens which are specifically applicable for pressure vessels as per ASTM D 2290 at ambient temperature.

\section{Test $\mathbf{- 3}$}

Experimental evaluation of apparent tensile strength on Carbon Epoxy filament wound ring specimens which are specifically applicable for pressure vessels as per ASTM D 2290 at above ambient temperatures.

\section{Test -4}

Determination of Glass Transition temperature ( $\mathrm{Tg}$ ) for Carbon Epoxy composite by Dry Scanning Calorimetry (DSC).

\section{Manufacturing of Uni-Directional Laminate and Flat Specimens}

\section{Uni-Directional Laminate}

In present studies, Carbon Epoxy Uni-Direction laminates are manufactured by wet filament winding process on rectangular mandrel by maintaining proper fiber tension and resin mix viscosity in resin bath. Resin and hardener are mixed in ratio of 100: 27. Resin batch is maintained at $45^{\circ} \mathrm{C}$ and resin mix viscosity is 900 to $1000 \mathrm{cps}$. In present work this manufacturing process is chosen as it simulates the actual process which is being followed for manufacturing of composite rocket motor case (Quanjin et al., 2020). The rectangular mandrel which is used to wind laminate is shown as follows in Figure 1. 


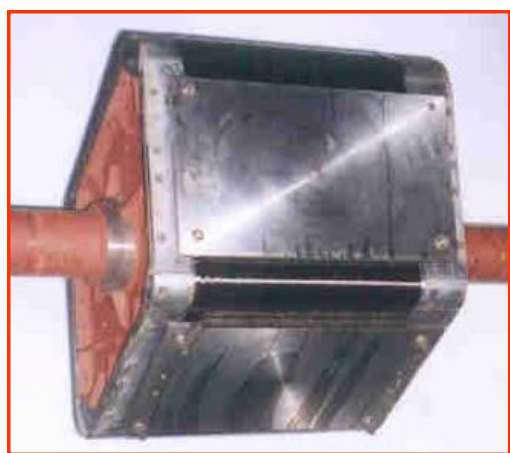

(a) Rectangular Mandrel

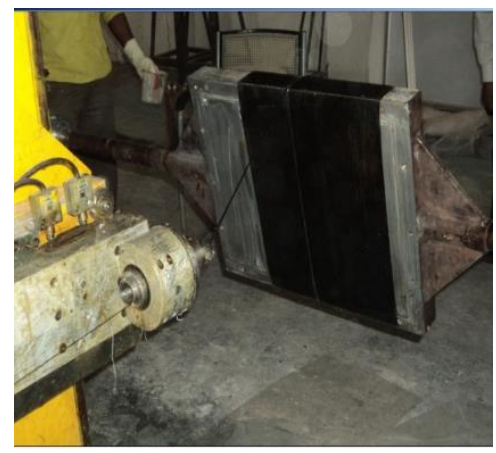

(b) Filament winding

Figure 1. Manufacturing of CE Uni-Directional laminate by filament winding.

Once filament winding gets completed, the laminate is cured in an oven having accurate temperature control (Mphahlele et al., 2019). The flat mandrel is placed inside the oven on metal stands. The following cure cycle is followed:

Temperature of the oven raised from room temperature to $120^{\circ} \mathrm{C}$ in 3 minutes with heating rate of 2 to $4^{\circ} \mathrm{C}$ per minute

- $\quad$ Temperature held at $120^{\circ} \mathrm{C} \pm 5^{\circ} \mathrm{C}$ for 3 hours.

- $\quad$ Temperature of the oven raised from $120^{\circ} \mathrm{C}$ to $160^{\circ} \mathrm{C}$ in 3 minutes with heating rate of 2 to $4^{\circ} \mathrm{C}$ per minute.

- $\quad$ Temperature held at $160^{\circ} \mathrm{C} \pm 5^{\circ} \mathrm{C}$ for 4 hours

- $\quad$ Switch off the oven and allow the component to cool naturally.

- $\quad$ Oven door got opened and mandrel is removed when temperature falls below $40^{\circ} \mathrm{C}$

\section{Specimen Preparation:}

Flat specimens are machined from laminate through diamond wheel cutting machine. The dimensions of specimens are maintained as per ASTM D 3039 given as follows in Figure 2, 3, and 4: 
International Journal of Aviation, Aeronautics, and Aerospace, Vol. 7 [2020], Iss. 4, Art. 8

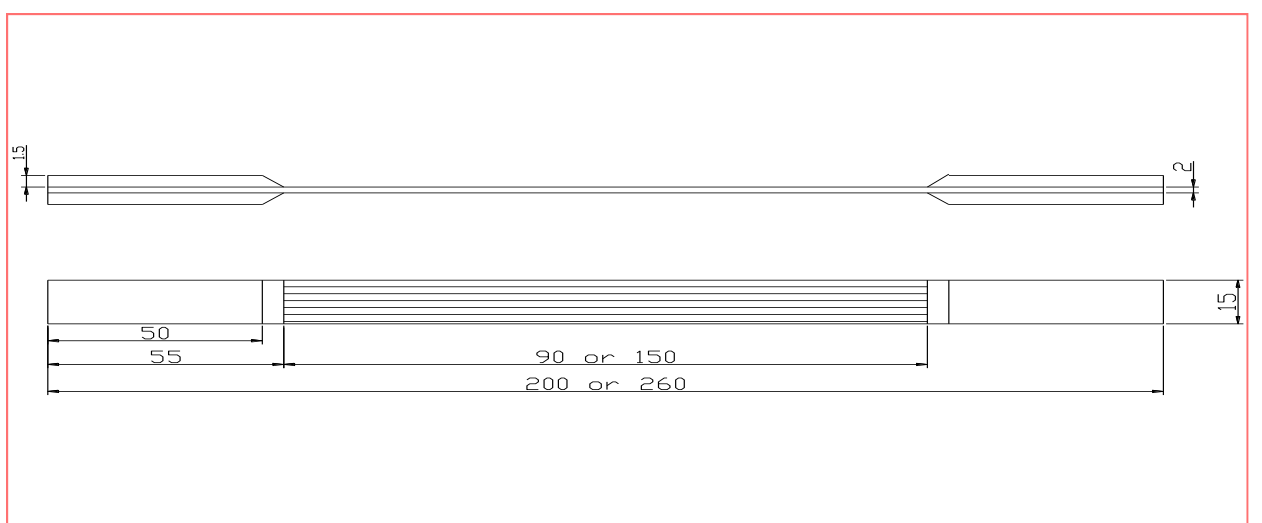

Figure 2. Longitudinal Flat Tensile Test Specimen (ASTM International, 2020b).

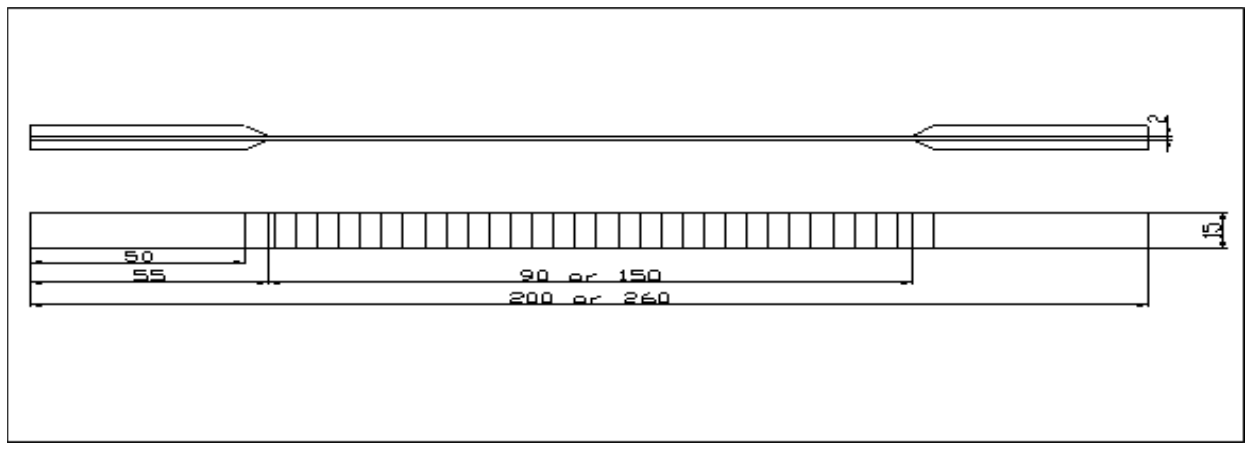

Figure 3. Transverse Flat Tensile Test Specimen (ASTM International, 2020b).

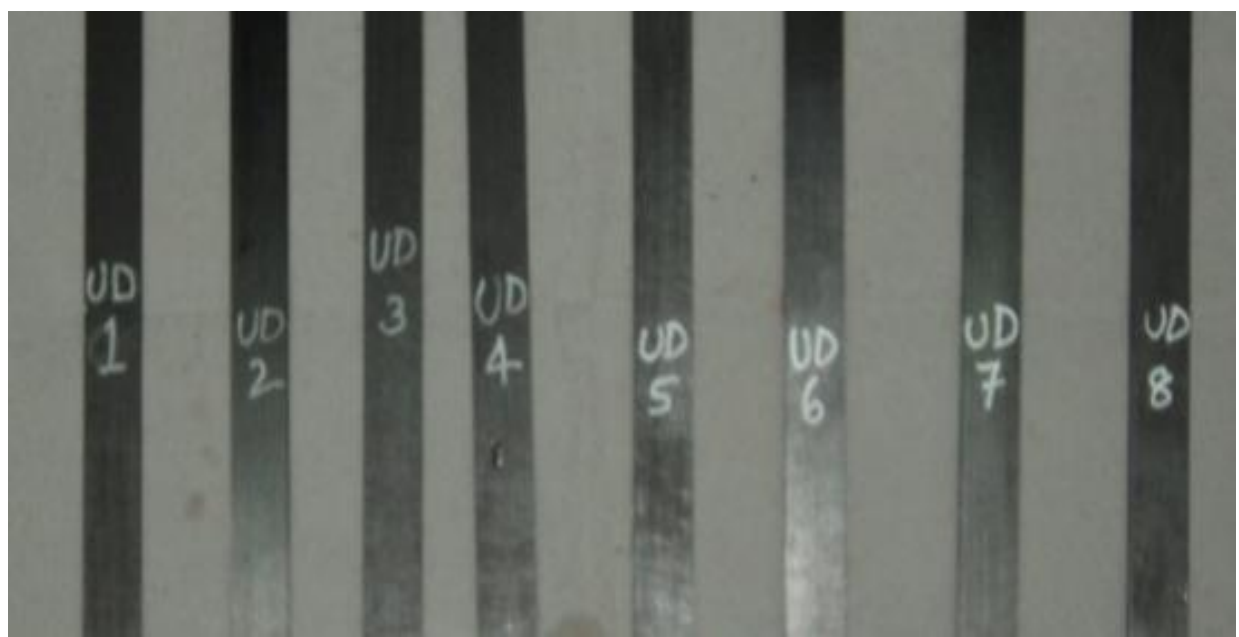

Figure 4. Uni-Directional Tensile Flat specimen. 


\section{Manufacturing of Composite Ring and Specimens}

Manufacturing of composite ring is carried out with wet filament winding process similar to Uni-Directional laminate through cylindrical mandrel instead of flat one. Once filament winding gets completed the mandrel is kept inside oven for curing as the same curing cycle mentioned in case of Uni-Directional laminate. Manufacturing is shown in following Figure 5:
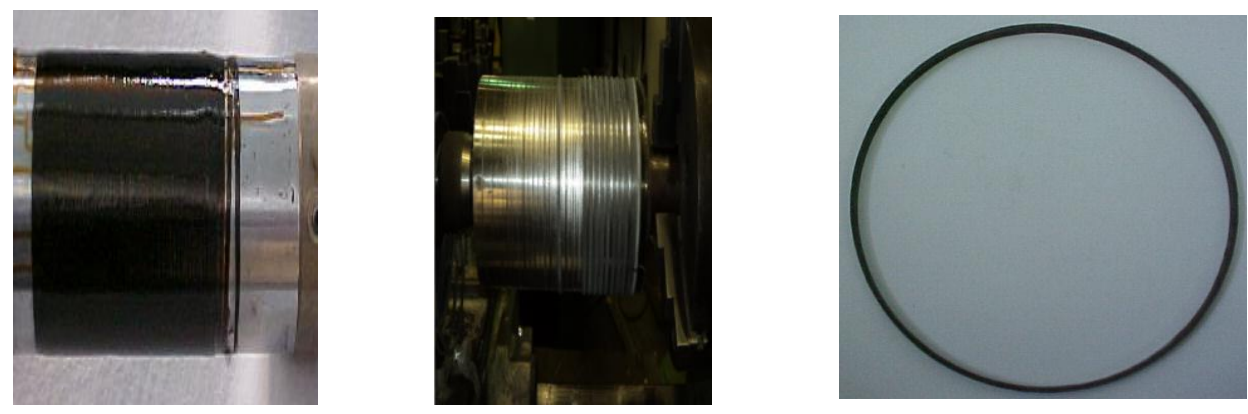

Figure 5. Manufacturing of Ring by filament winding process \& Specimen.

The Ring specimen dimensions are maintained as per ASTM D 2290 given as follows in Figure 6:

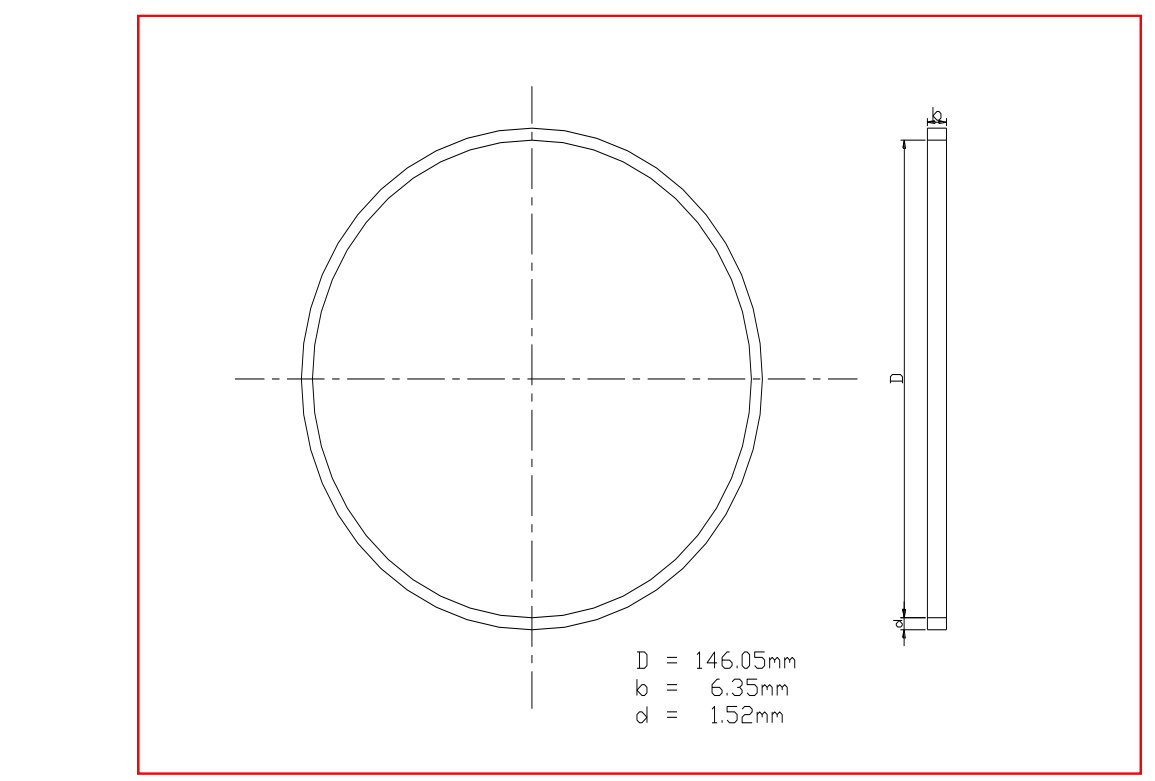

Figure 6. Ring Specimen (ASTM International, 2020a). 


\section{Testing and Results}

Experimental evaluation of Carbon Epoxy composites are carried through mechanical testing on $100 \mathrm{KN}$ capacity UTM along with strain data acquisition system as per test scheme mentioned above. The details regarding tests, test methods and results are given as follows:

\section{Mechanical Testing of laminate Specimens (Test-1)}

Testing is carried out on specimens made from Uni-Directional Carbon Epoxy Laminate as per ASTM D 3039 for evaluation of Tensile strength, tensile modulus, Poisons ratio and Ultimate failure strain at ambient temperature. Twentyfive specimens are tested for mechanical properties.

\section{Test Results}

The stress- strain plot obtained tensile testing for longitudinal specimen is given as follows in Figure 7:

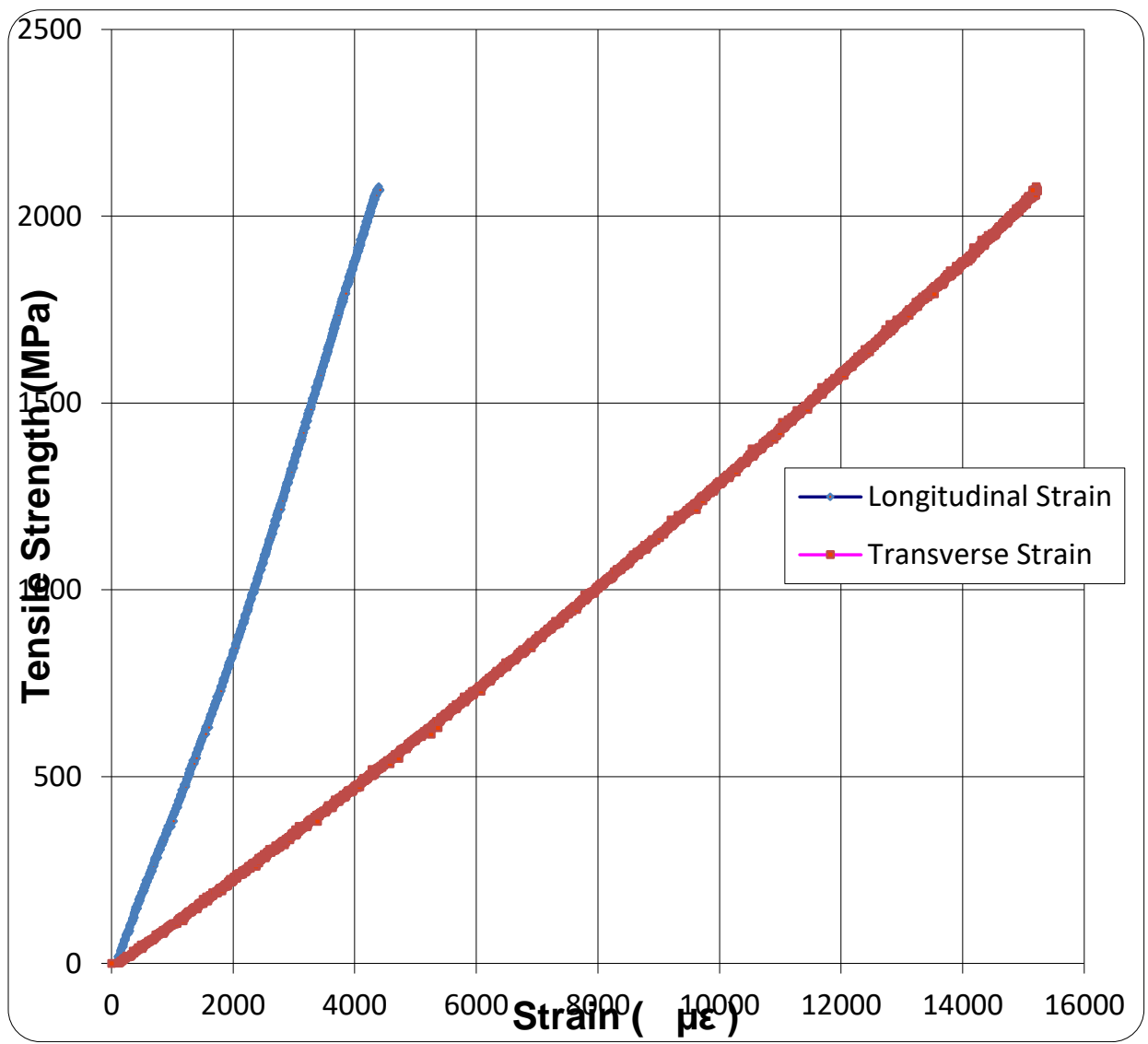

Figure 7. Stress - Strain plot for Carbon-Epoxy composite tensile test.

In present study test results for mechanical properties of longitudinal flat specimens are of interest however from laminate Transverse flat specimens are also 
prepared and tested for mechanical properties. 20 longitudinal specimens and 15 transverse specimens are tested. Physical properties viz fiber volume fraction and CE composite density are also determined which are important parameters for various correlation for composite characteristics and properties apart from design aspects. The test results for mechanical properties and physical properties are given in following Table 3.

Table 3

Test results for CE composite mechanical and Physical Properties

\begin{tabular}{|c|c|c|c|c|c|}
\hline l.NO & PROPERTY & ASTM No & $\begin{array}{l}\text { No. of } \\
\text { Specimens }\end{array}$ & $\begin{array}{l}\text { Average } \\
\text { Value }\end{array}$ & $\% C V$ \\
\hline .0 & \multicolumn{3}{|c|}{ MECHANICAL PROPERTIES } & & \\
\hline .1 & $\begin{array}{l}\text { Longitudinal Tensile } \\
\text { Strength }(\mathrm{MPa})\end{array}$ & \multirow{5}{*}{ D3039 } & \multirow{3}{*}{20} & 2220 & 8.90 \\
\hline .2 & $\begin{array}{l}\text { Longitudinal Tensile } \\
\text { Modulus (MPa) }\end{array}$ & & & 128 & 3.40 \\
\hline .3 & $\begin{array}{l}\text { Major Poison's ratio, } \\
v_{12}\end{array}$ & & & 0.29 & 5.17 \\
\hline .4 & $\begin{array}{l}\text { Transverse Tensile } \\
\text { Strength }(\mathrm{MPa})\end{array}$ & & \multirow[t]{2}{*}{15} & 18.5 & 14.50 \\
\hline .5 & $\begin{array}{ll}\text { Transverse } & \text { Tensile } \\
\text { Modulu (MPa) } & \end{array}$ & & & 9.5 & 10.60 \\
\hline .0 & \multicolumn{3}{|c|}{ PHYSICAL PROPERTIES } & & \\
\hline .1 & $\begin{array}{l}\text { Fiber volume fraction, } \\
\mathrm{V}_{\mathrm{f}}\end{array}$ & D3171 & 3 & 60 & - \\
\hline .2 & Density $(\rho), g / c c$ & D792 & 3 & 1.54 & \\
\hline
\end{tabular}

Testing of Ring Specimens at ambient temperature (Test -2)

The Carbon Epoxy filament wound ring specimens which are specifically applicable for pressure vessels are tested as per ASTM D 2290 at ambient temperature. In this test specimen is loaded through split disc test fixture which facilitates for alignment during loading. During test as bending moment is also imposed an apparent tensile strength is determined instead of true tensile strength. The apparent tensile strength is less than actual tensile strength but ring specimens 
closely simulates composite pressure vessels and test results are highly useful for various correlation. Evaluation of tensile modulus is not possible in this test. Split disc fixture design is done in such a way that it reduces the bending moment. This test is highly significant for various aspects of composite pressure vessels.

\section{Test Results}

The tensile strength and displacement plot for this test is given as follows in Figure 8:

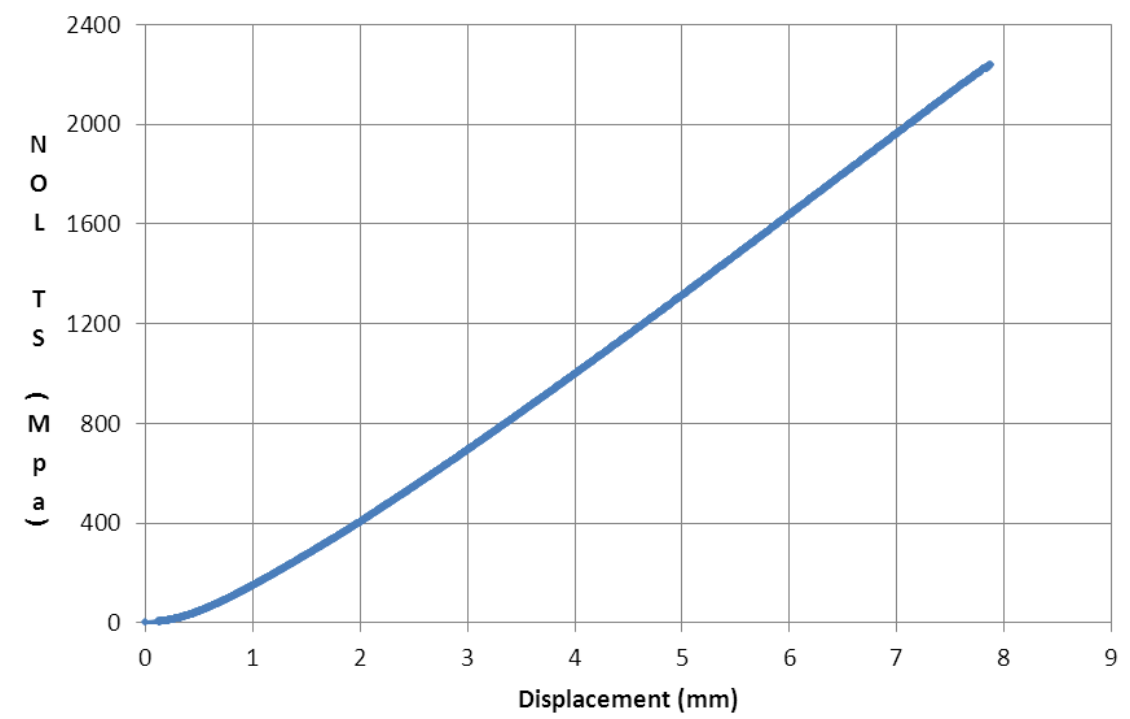

Figure 8. Tensile strength and displacement plot.

In present experimental evaluation, ten specimens are prepared and tested for apparent tensile strength. The test results are given in following Table 4: 
Table 4

Tensile Strength for Ring Specimens with Temperature

\begin{tabular}{|c|c|}
\hline Ring Specimens & Tensile Strength (MPa) \\
\hline 1 & 1913 \\
\hline 2 & 2116 \\
\hline 3 & 2089 \\
\hline 4 & 1888 \\
\hline 5 & 2178 \\
\hline 6 & 1865 \\
\hline 7 & 2057 \\
\hline 8 & 1784 \\
\hline 9 & 2228 \\
\hline 10 & 1935 \\
\hline Average & 2005 \\
\hline \% Coefficient & 148 \\
\hline of Variance & 7.35 \\
\hline
\end{tabular}

Testing of Ring Specimens at above ambient temperatures (Test -3)

The Carbon Epoxy filament wound ring specimens are tested as per ASTM D 2290 at ambient temperatures more than ambient. The prime objective of this test is to experimentally determine the temperature at which tensile strength degradation starts for CE composite. In this test five specimens are tested at each temperature. Test is carried out from ambient temperature up to $130^{\circ} \mathrm{C}$.

Test Results

The test results for tensile strength at each temperature for all five specimens are given in following Table 5: 
Table 5

Tensile strength for ring specimens with temperature

\begin{tabular}{|c|c|c|c|c|}
\hline Temperature & \multicolumn{2}{|c|}{ Strength $(M P a)$} & $\begin{array}{l}\text { Average Tensile } \\
\text { Strength }(\mathrm{MPa})\end{array}$ & $\begin{array}{c}\text { \% Drop in Tensile } \\
\text { Strength }\end{array}$ \\
\hline \multirow{6}{*}{ Ambient } & Specimen 1 & 000 & \multirow{6}{*}{1947.6} & \multirow[t]{6}{*}{------- } \\
\hline & Specimen 2 & 020 & & \\
\hline & & 920 & & \\
\hline & & 936 & & \\
\hline & Specimen 4 & 041 & & \\
\hline & Specimen 5 & 841 & & \\
\hline & Specimen 1 & 881 & & \\
\hline $100^{\circ} \mathrm{C}$ & Specimen 2 & & 1862.6 & 4.3 \\
\hline & & 826 & & \\
\hline & Specimen 3 & 888 & & \\
\hline & Specimen 4 & & & \\
\hline & & 871 & & \\
\hline & Specimen 5 & 847 & & \\
\hline & Specimen 1 & 871 & & \\
\hline $110^{\circ} \mathrm{C}$ & Specimen 2 & & 1798.2 & 7.6 \\
\hline & & 779 & & \\
\hline & Specimen 3 & 804 & & \\
\hline & Specimen 4 & & & \\
\hline & & 790 & & \\
\hline & Specimen 5 & 747 & & \\
\hline & Specimen 1 & 650 & & \\
\hline $120^{\circ} \mathrm{C}$ & Specimen 2 & 610 & 1648.2 & 15.3 \\
\hline & Specimen 3 & 612 & & \\
\hline & & 712 & & \\
\hline
\end{tabular}




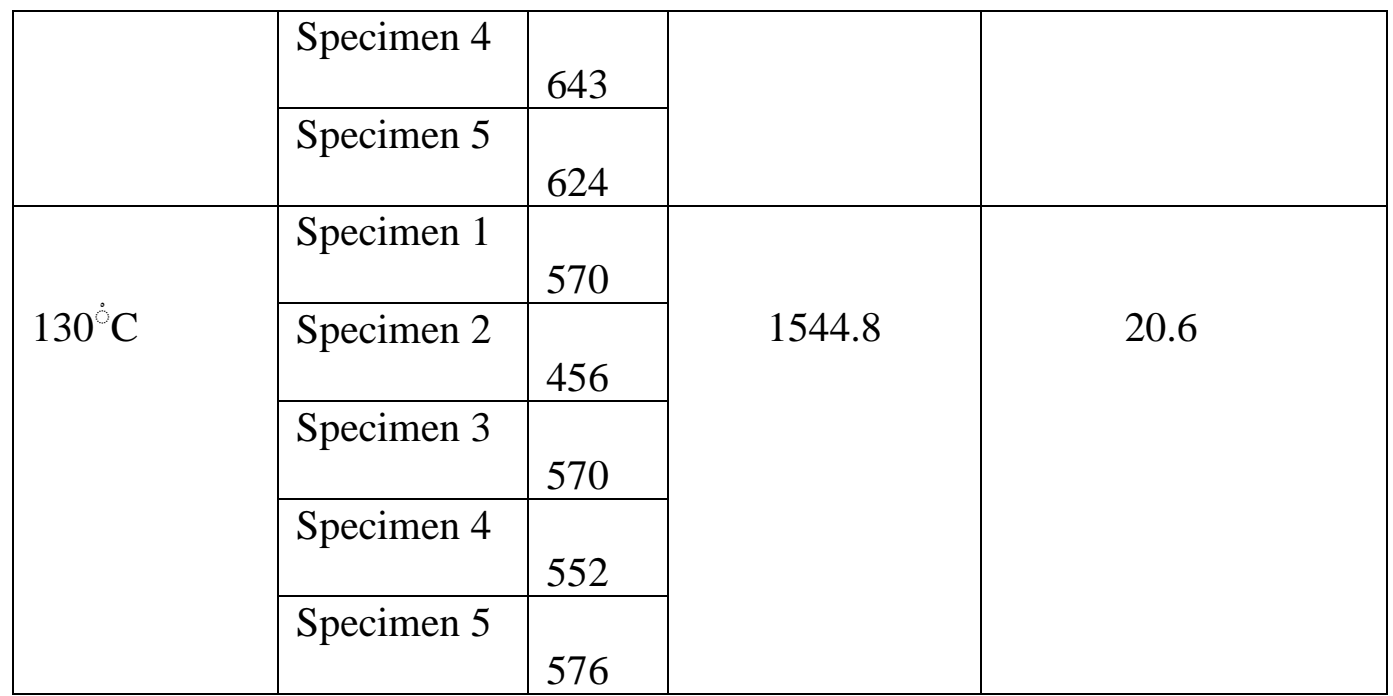

The Tensile strength and temperature plot are given as follows in Figure 9.

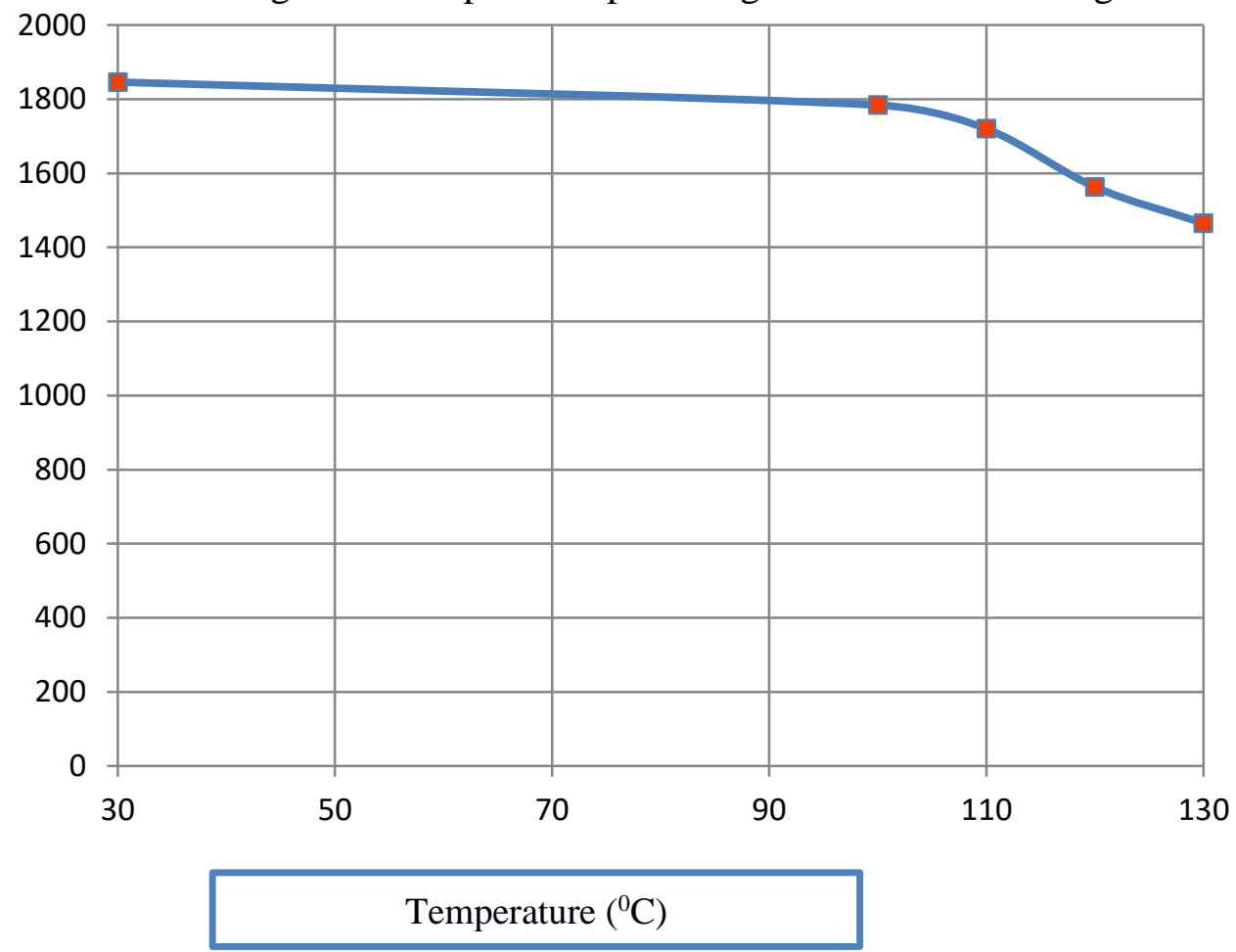

Figure 9. Tensile strength and Temperature plot. 


\section{Determination of Glass Transition Temperature (Test-4)}

In present study the Glass transition temperature for CE composite is determined with Dry scanning Calorimetry technique as per ASTM E 1256. Differential Scanning Calorimetry, or DSC, is a thermal test method in which change in heat capacity of material is monitored and recorded with respect to temperature. In this technique, specimen of measured mass is subjected to heating or cooling and change in heat flow is recorded which in turn is correlated with change in heat capacity. This allows the detection of transitions such as melts, glass transitions, phase changes, and curing.

\section{Test Results:}

Glass transition temperature for CE sample is $161^{\circ} \mathrm{C}$. DSC run plot for heat flow and temperature for $\mathrm{CE}$ sample is given below in Figure 10:

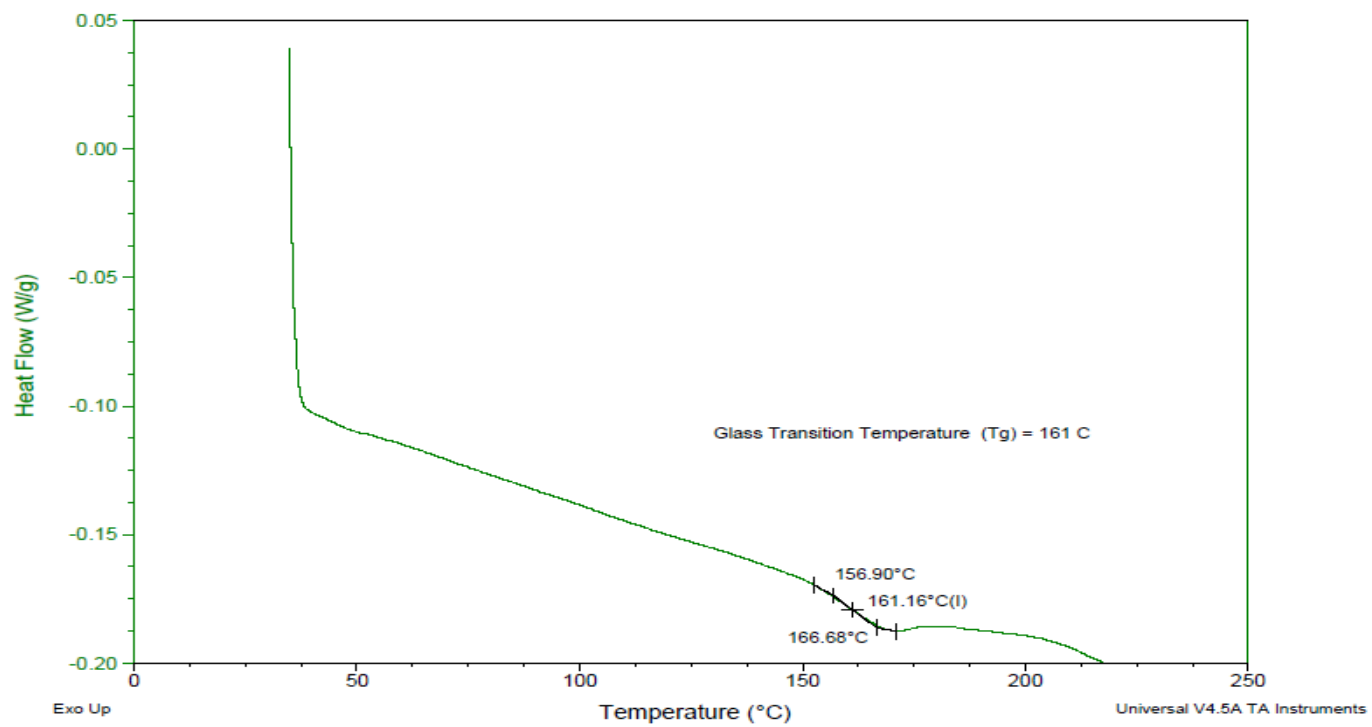

Figure 10. Heat flow and temperature plot through DSC.

\section{Conclusions}

In present studies, the mechanical properties test results for flat specimens prepared from UD laminates are correlated with tensile strength evaluated on ring specimens. The mechanical properties obtained from Test -1 are used for design and analysis of carbon epoxy structure however filament wound rings simulate closely with composite rocket motor casing in terms of process and fiber orientations particularly in hoop direction. The tensile strength obtained through ring specimen is apparent tensile strength as in testing bending moment also exists though effect is minimised through split disc test fixture. The correlation and 
comparative analysis of test results from test- 1 and test 2 is good basis to effectively exploit merits of both namely mechanical properties test results used as design inputs and apparent tensile strength process and application. In case of filament wound composite structure like rocket motor case ring specimens are vital.

The present study is with objective of generating experimental data for tensile strength with respect to temperature in order to establish the constraint on external surface temperature of composite rocket motor case for design of various trajectories and vehicle configurations. This is fundament requirement to evolve scheme and design thermal protection system for composite case. Ring specimens simulate closely with this requirement and tested for temperatures above the ambient in test-3 to generate data for tensile strength with respect to temperature. In test results it is observed that tensile strength is degraded from 1947.6 Mpa at ambient to $1862.6 \mathrm{MPa}$ at $100^{\circ} \mathrm{C}$. In case of polymeric composites apart from strength degradation temperature, the glass transition temperature is also important. In test-4, the glass transition temperature of Carbon Epoxy composite is also determined by DSC technique which is $161^{\circ} \mathrm{C}$. The test results for strength degradation temperature and glass transition temperature for carbon Epoxy composite provides basis to design structural layer considering kinetic heating effect and design of thermal protection system. 


\section{References}

ASTM International. (2020a). ASTM D2290 standard, standard test method for apparent hoop tensile strength of plastic or reinforced plastic pipe.

Retrieved from https://www.astm.org/Standards/D2290

ASTM International. (2020b). ASTM D3039 standard, test method for tensile properties of polymer matrix composite materials. Retrieved from https://www.astm.org/Standards/D3039

Bannov, A.G., Brester, A. E., Shestakov, A. A., Popov, M.V., Lapekin, N. I., \& Krivyakin, G. K. (2020). Technological characteristics of epoxy/carbon black composites. Materials Today Proceedings. 10.1016/j.matpr.2020.05.758

Ford, E. (2020). Filament winding composite airframes for sounding rockets. Scholarly Commons. Retrieved from https://commons.erau.edu/studentworks/157/

Liu, F., Shi, Z., \& Yubing Dong, Y. (2018). Improved wettability and interfacial adhesion in carbon fibre/epoxy composites via an aqueous epoxy sizing agent. Composites Part A: Applied Science and Manufacturing, 112, 337345. https://doi.org/10.1016/j.compositesa.2018.06.026

Liu, Y., Delong H., Hamon, A.-L., Fan, B., Haghi-Ashtiani, P., Reiss, T., \& Bai, J. (2018). Comparison of different surface treatments of carbon fibers used as reinforcements in epoxy composites: Interfacial strength measurements by in-situ scanning electron microscope tensile tests. Composites Science and Technology, 167, 331-338. https://doi.org/10.1016/ j.compscitech.2018.08.018

Mphahlele, K., Sinha Ray, S., \& Kolesnikov, A. (2019). Cure kinetics, morphology development, and rheology of a high-performance carbonfiber-reinforced epoxy composite. Composites Part B: Engineering , 176. https://doi.org/10.1016/j.compositesb.2019.107300

Muralidhara, B., Kumaresh Babu, S. P., \& Suresha, B. (2020). The effect of fiber architecture on the mechanical properties of carbon/epoxy composites. Materials Today Proceedings, 22(4), 1755-1764. https://doi.org/10.1016/ j.matpr.2020.03.008

Quanjin, M., Rejab, M. R. M., Kaige, J., Idris, M. S., \& Harith, M. N. (2020). Filament winding technique, experiment and simulation analysis on tubular structure. IOP Conference Series: Materials Science and 
Engineering, 342, conference 1. Retrieved from https://iopscience.iop.org/ article/10.1088/1757-899X/342/1/012029

Rajak, D. K., Pagar, D. D., Kumar, R., \& Pruncu, C. I. (2019). Recent progress of reinforcement materials: a comprehensive overview of composite materials. Journal of Materials Research and Technology, 8(6), 63546374. https://doi.org/10.1016/j.jmrt.2019.09.068

Raju, A., \& Shanmugaraja, M. (2020). Recent researches in fiber reinforced composite materials: A review. Materialstoday Proceedings. https://doi.org/10.1016/j.matpr.2020.02.141

Sharma, A. K., Bhandari, R., Aherwar, A., \& Rimasauskiene, R. (2020). Matrix materials used in composites: A comprehensive study. Materials Today Proceedings, 21(3), 1559-1562. https://doi.org/10.1016/j.matpr. 2019.11.086

Shen, X.-J., Dang, C.-Y., Tang, Tang, B.-L., Yang, X.-H., Nie, H.-J., Lu, J.-J., Zhang, T.-T., \& Friedrich, K. (2020). The reinforcing effect of oriented graphene on the interlaminar shear strength of carbon fabric/epoxy composites. Materials \& Design, 185, 108-257. https://doi.org/10.1016/ j.matdes.2019.108257

Trudeau, H. D. (1990). The advanced solid rocket motor project. International Journal of Aviation, Aeronautics, and Aerospace, The Space Congress $27^{\text {th }}$ Proceedings. https://commons.erau.edu/space-congress-proceedings/ proceedings-1990-27th/april-26-1990/16/

Weber, T. A. (2017). Advances in composite manufacturing of helicopter parts. International Journal of Aviation, Aeronautics, and Aerospace, 4. https://commons.erau.edu/cgi/viewcontent.cgi? article=1153\&context=ijaa a 